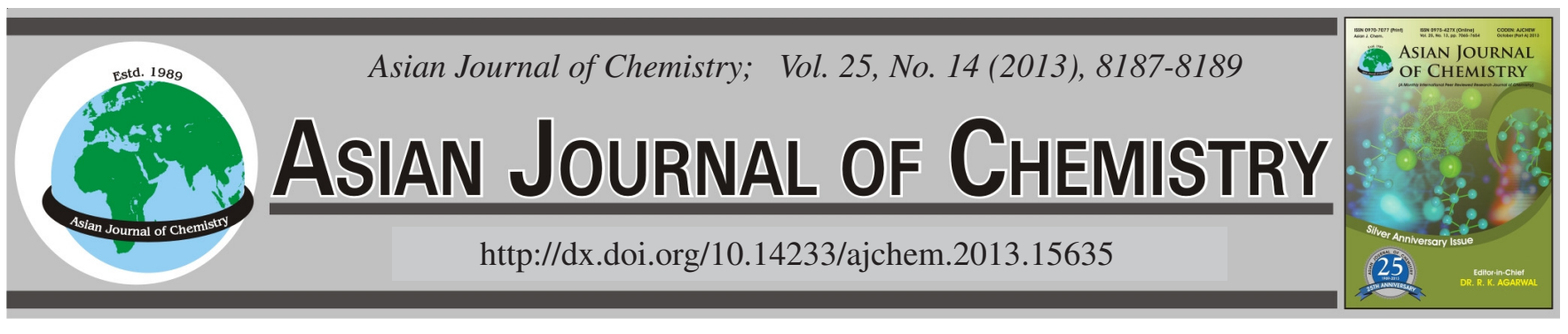

\title{
Synthesis and Crystal Structure of Dialkoxo-Bridged Dinuclear Cu(II) Complex with 5-Methoxy-6'-hydroxy-2,2'-[ethylenedioxybis(nitrilomethylidyne)]diphenol
}

\author{
Xin-Ying Zhang ${ }^{*}$, Li-Sha Zhang, Peng-Fei Liu, Cheng-Juan Yang, Zheng-Kun Wang and Jiao-Long Meng
}

School of Chemical and Biological Engineering, Lanzhou Jiaotong University, Lanzhou 730070, P.R. China

*Corresponding author: E-mail: zhangxy_88@126.com

\begin{abstract}
An unexpected dinuclear copper(II) complex, $\left[\mathrm{Cu}_{2}\left(\mathrm{~L}^{2}\right)_{2}\right]\left(\mathrm{H}_{2} \mathrm{~L}^{2}=4\right.$-methoxysalicylaldehyde-O-(2-hydroxyethyl)oxime), has been synthesized through the complexation of $\mathrm{Cu}(\mathrm{OAc})_{2} \cdot \mathrm{H}_{2} \mathrm{O}$ with an asymmetrical salamo-type compound 5-methoxy-6'-hydroxy-2,2'[ethylenedioxybis(nitrilomethylidyne)]diphenol $\left(\mathrm{H}_{3} \mathrm{~L}^{1}\right)$. The catalysis of $\mathrm{Cu}$ (II) ions results in the unexpected cleavage of one of the $\mathrm{N}-\mathrm{O}$ bonds in the ligand $\mathrm{H}_{3} \mathrm{~L}^{1}$, giving a novel dialkoxo-bridged dinuclear $\mathrm{Cu}$ (II) complex possessing a $\mathrm{Cu}-\mathrm{O}-\mathrm{Cu}-\mathrm{O}$ four membered ring core instead of the usually desired salamo-type ligand $\mathrm{Cu}-\mathrm{N}_{2} \mathrm{O}_{2}$ mononuclear complex.

Key Words: Asymmetrical salamo-type compound, $\mathrm{Cu}(\mathrm{II})$ complex, Synthesis, Crystal structure.
\end{abstract}

\section{INTRODUCTION}

Particular attention has recently been paid to the synthesis and crystal structure of salamo-type compounds and their analogues ${ }^{1,2}$. These compounds can easily form polynuclear complexes in which the metal centers are bridged through organic ligands, because of their enormous variety of structural topologies as well as their unique properties in host-guest chemistry, magnetism, asymmetric catalysis, electronic conductivity $^{3-6}$. This subject is currently being pursued in our research, including the applications and study of salamo-type compounds and their metal complexes.

In this article, we report the synthesis and crystal structure of a dinuclear $\mathrm{Cu}(\mathrm{II})$ complex $\left[\mathrm{Cu}_{2}\left(\mathrm{~L}^{2}\right)_{2}\right]$ with the new ligand 4-methoxysalicylaldehyde-O-(2-hydroxyethyl) oxime $\left(\mathrm{H}_{2} \mathrm{~L}^{2}\right)$ which is formed in the course of complexation of an asymmetrical salamo-type compound 5-methoxy-6'-hydroxy-2,2'[ethylenedioxybis(nitrilomethylidyne)]diphenol $\left(\mathrm{H}_{3} \mathrm{~L}^{1}\right)$ and $\mathrm{Cu}(\mathrm{II})$ acetate monohydrate. The obtained results show cleavage of one of the $\mathrm{N}-\mathrm{O}$ bonds in $\mathrm{H}_{3} \mathrm{~L}^{1}$ in the complexation of the ligand $\mathrm{H}_{3} \mathrm{~L}^{1}$ with $\mathrm{Cu}(\mathrm{OAc})_{2} \cdot \mathrm{H}_{2} \mathrm{O}$ and give an unexpected dialkoxo-bridged dinuclear $\mathrm{Cu}$ (II) complex possessing a $\mathrm{Cu}-\mathrm{O}-\mathrm{Cu}-\mathrm{O}$ four-membered ring core instead of the usually desired salamo-type $\mathrm{Cu}-\mathrm{N}_{2} \mathrm{O}_{2}$ complex.

\section{EXPERIMENTAL}

2-Hydroxy-4-methoxybenzaldehyde ( $\geq 99 \%$ ) was purchased from Energy Chemical and used without further purification. The others are the same as literature early ${ }^{1 \mathrm{i}}$.

\section{General procedure}

Synthesis of the ligand $\mathbf{H}_{3} \mathbf{L}^{1}$ : The major reaction steps involved in the synthesis of $\mathrm{H}_{3} \mathrm{~L}^{1}$ are given in Scheme-I.

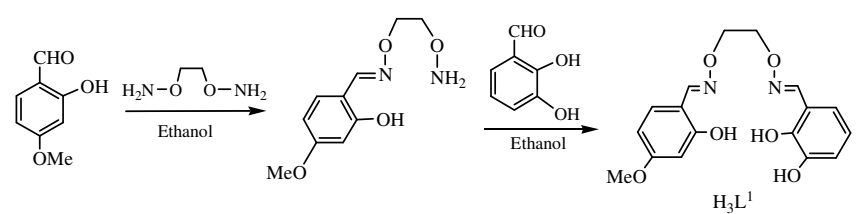

Scheme-I: Synthetic route to the asymmetrical salamo-type compound $\mathrm{H}_{3} \mathrm{~L}^{1}$

1,2-Bis(phthalimidoxy)ethane was prepared according to the literature ${ }^{1}$. Yield $87.5 \%$. m.p. $250{ }^{\circ} \mathrm{C}$. 1,2-Bis(aminooxy)ethane was synthesized according to an analogous method reported previously ${ }^{1}$. Monooxime compound was synthesized with a slightly modified method reported previously in the literature ${ }^{1,7}$. Yield $75.1 \%$. m.p. $41-42{ }^{\circ} \mathrm{C}$. Anal. calcd. for $\mathrm{C}_{10} \mathrm{H}_{14} \mathrm{~N}_{2} \mathrm{O}_{4}(\%)$ : C, 53.09; H, 6.24; N, 12.38; found (\%): C, 53.22; H, 6.27; N, 12.24.

For $\mathrm{H}_{3} \mathrm{~L}^{1}$, to an ethanol solution $(10 \mathrm{~mL})$ of the monooxime compound (226.0 mg, $1.00 \mathrm{mmol}$ ) was added dropwise an ethanol solution $(8 \mathrm{~mL})$ of 2,3-dihydroxybenzaldehyde (138 $\mathrm{mg}, 1 \mathrm{mmol})$. The mixture solution was heated at $55-60^{\circ} \mathrm{C}$ for $5 \mathrm{~h}$. When the mixture cooled to room temperature, the precipitate was filtered and washed successively with ethanol and ethanol/hexane (1:4), respectively. The product was dried in vacuo and obtained $236.1 \mathrm{mg}$ of white solid. Yield $68.2 \%$. 
m.p. $110-112^{\circ} \mathrm{C}$. Anal. calcd. for $\mathrm{C}_{17} \mathrm{H}_{18} \mathrm{~N}_{2} \mathrm{O}_{6}(\%)$ : C, 58.96; H, 5.24; N, 8.09. Found (\%): C, 59.17; H, 5.13; N, 8.01.

Synthesis of the $\mathrm{Cu}($ II) complex: A solution of $\mathrm{Cu}(\mathrm{OAc})_{2} \cdot \mathrm{H}_{2} \mathrm{O}(2.00 \mathrm{mg}, 0.01 \mathrm{mmol})$ in methanol $(3 \mathrm{~mL})$ was added dropwise to a solution of $\mathrm{H}_{3} \mathrm{~L}^{1}(3.46 \mathrm{mg}, 0.01 \mathrm{mmol})$ in acetone $(1 \mathrm{~mL})$ at room temperature. The colour of the mixing solution turned to brown immediately, then stirred for $1 \mathrm{~h}$ at room temperature. The mixture was filtered off and the filtrate was allowed to stand at room temperature for about three weeks, the solvent was partially evaporated and obtained brown prismatical single crystals suitable for $\mathrm{X}$-ray crystallographic analysis. Anal. calcd. for $\mathrm{C}_{20} \mathrm{H}_{22} \mathrm{~N}_{2} \mathrm{O}_{8} \mathrm{Cu}_{2}$ (\%): C, 44.04; $\mathrm{H}$, 4.07; N, 5.14; Cu, 23.30. Found (\%): C, 43.96; H, 4.19; N, 5.03; Cu, 23.46.

X-Ray structure determination: The X-ray structure determination is the same as literature early ${ }^{1 i}$. Details of the data collection and refinements of title compound are listed in Table-1. CCDC: 933601.

\begin{tabular}{|c|c|}
\hline \multicolumn{2}{|c|}{$\begin{array}{l}\text { TABLE- } 1 \\
\text { CRYSTAL DATA AND STRUCTURE } \\
\text { REFINEMENT FOR THE COMPLEX }\end{array}$} \\
\hline Empirical formula & $\mathrm{C}_{20} \mathrm{H}_{22} \mathrm{~N}_{2} \mathrm{O}_{8} \mathrm{Cu}_{2}$ \\
\hline Formula weight & 545.48 \\
\hline Temperature (K) & 293(2) \\
\hline Wavelength $(\AA)$ & 0.71073 \\
\hline Crystal system & Monoclinic \\
\hline Space group & $\mathrm{P} 2_{1} / \mathrm{c}$ \\
\hline Cell dimensions, $\left(\AA^{\circ}{ }^{\circ}\right)$ & $\begin{array}{l}\mathrm{a}=5.2234(5), \mathrm{b}=15.317(2) \\
\mathrm{c}=12.976(1), \beta=100.294(1)\end{array}$ \\
\hline Volume $\left(\AA^{3}\right)$ & $1021.5(2)$ \\
\hline $\mathrm{Z}$ & 2 \\
\hline Density (calculated) (mg/m³) & 1.773 \\
\hline Absorption coefficient $\left(\mathrm{mm}^{-1}\right)$ & 2.135 \\
\hline $\mathrm{F}_{(000)}$ & 556 \\
\hline Index ranges & $-6 \leq \mathrm{h} \leq 6,-6 \leq \mathrm{k} \leq 18,-15 \leq 1 \leq 14$ \\
\hline Reflections collected & $3319 / 1797\left[\mathrm{R}_{\text {(int) }}=0.0252\right]$ \\
\hline Independent reflections & 886 \\
\hline Data/restraints/parameters & $1797 / 0 / 146$ \\
\hline Goodness of fit indicator & 1.057 \\
\hline $\mathrm{R}[\mathrm{I}>2 \sigma(\mathrm{I})]$ & $\mathrm{R}_{1}=0.0348, \mathrm{wR}_{2}=0.0822$ \\
\hline Largest diff. peak and hole $\left(\mathrm{e} \AA^{-3}\right)$ & 0.334 and -0.281 \\
\hline RESULTS AN & DISCUSSION \\
\hline
\end{tabular}

Crystal structure of the $\mathbf{C u}($ III) complex: For the synthesis of the $\mathrm{Cu}(\mathrm{II})$ complex $\left[\mathrm{Cu}_{2}\left(\mathrm{~L}^{2}\right)_{2}\right]$, the same synthetic route was used for the mononuclear complex according to the previous work ${ }^{1}$. However, it is remarkable that an unexpected dinuclear
$\mathrm{Cu}$ (II) complex $\left[\mathrm{Cu}_{2}\left(\mathrm{~L}^{2}\right)_{2}\right]$ was obtained, instead of the desired salamo-type complex $\left[\mathrm{Cu}\left(\mathrm{L}^{1}\right)\right]$, which was formed in the course of the complexation of $\mathrm{H}_{3} \mathrm{~L}^{1}$ and $\mathrm{Cu}(\mathrm{OAc})_{2} \cdot \mathrm{H}_{2} \mathrm{O}$. The results show that because of the catalysis of $\mathrm{Cu}$ (II) ions $^{8,9}$, the complexation resulted in a cleavage of one of the $\mathrm{N}-\mathrm{O}$ bonds in $\mathrm{H}_{3} \mathrm{~L}^{1}$, giving a new O-N-O tridentate ligand $\mathrm{H}_{2} \mathrm{~L}^{2}$, which coordinates with $\mathrm{Cu}$ (II) ions forming a dialkoxo-bridged dinuclear $\mathrm{Cu}$ (II) complex ${ }^{10,11}$ with a $\mathrm{Cu}-\mathrm{O}-\mathrm{Cu}-\mathrm{O}$ four-membered ring core instead of the expected salamo-type $\mathrm{Cu}-\mathrm{N}_{2} \mathrm{O}_{2}$ complex (Scheme-II).

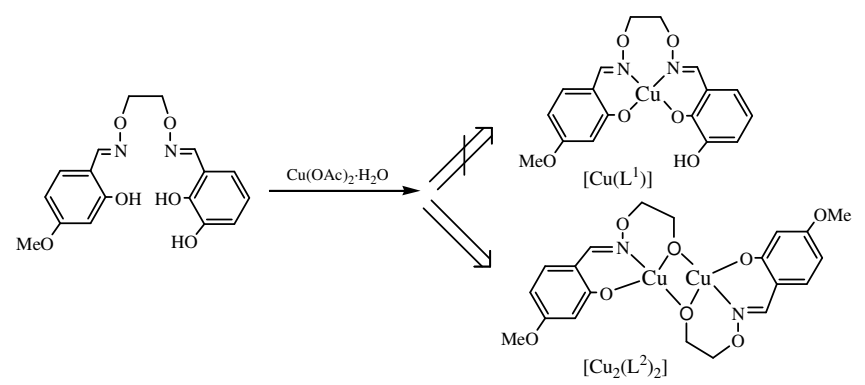

(a) Complexation of the ligand $\mathrm{H}_{3} \mathrm{~L}^{1}$ with $\mathrm{Cu}(\mathrm{OAc})_{2} \cdot \mathrm{H}_{2} \mathrm{O}$

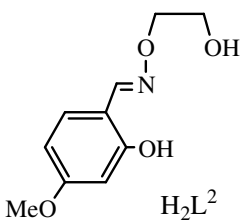

(b) 4-Methoxysalicylaldehyde-O-(2-hydroxyethyl)oxime $\left(\mathrm{H}_{2} \mathrm{~L}^{2}\right)$

Scheme-II: Complexation of $\mathrm{H}_{3} \mathrm{~L}^{1}$ with $\mathrm{Cu}(\mathrm{OAc})_{2} \cdot \mathrm{H}_{2} \mathrm{O}$ and chemical structure of $\mathrm{H}_{2} \mathrm{~L}^{2}$

The molecular structure and crystallographic atom numbering of the complex $\left[\mathrm{Cu}_{2}\left(\mathrm{~L}^{2}\right)_{2}\right]$ are given in Fig. 1. Selected bond lengths and bond angles are listed in Table-2.

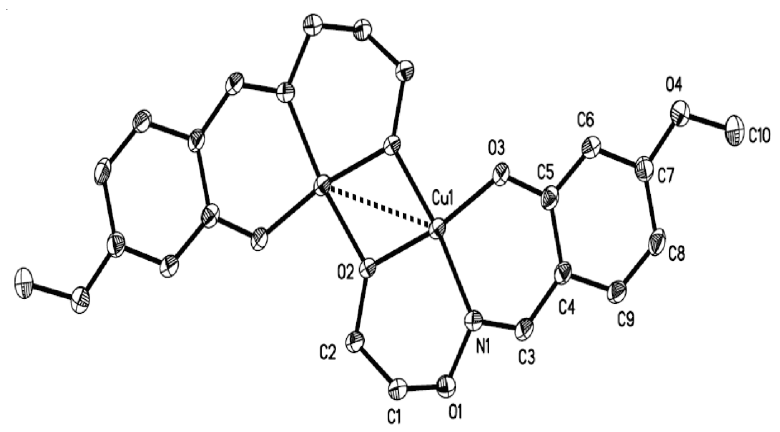

Fig. 1. ORTEP-style drawing of the $\mathrm{Cu}(\mathrm{II})$ complex

TABLE-2

SELECTED BOND DISTANCES $(\AA)$ AND ANGLES $\left({ }^{\circ}\right)$ FOR THE COMPLEX

\begin{tabular}{|c|c|c|c|c|c|}
\hline Bond & Lengths & Bond & Lengths & Bond & Lengths \\
\hline $\mathrm{Cu} 1-\mathrm{O} 3$ & $1.879(2)$ & $\mathrm{Cu} 1-\mathrm{O} 2$ & $1.904(2)$ & $\mathrm{Cu} 1-\mathrm{O} 2^{\# 1}$ & $1.912(2)$ \\
\hline $\mathrm{Cu} 1-\mathrm{N} 1$ & $1.935(3)$ & $\mathrm{Cu} 1-\mathrm{Cu} 1^{\# 1}$ & $2.999(1)$ & $\mathrm{O} 2-\mathrm{Cu} 1^{\# 1}$ & $1.912(2)$ \\
\hline Bond & Angles & Bond & Angles & Bond & Angles \\
\hline O3-Cu1-O2 & $170.5(1)$ & O3-Cu1-O2 $2^{\# 1}$ & $94.4(1)$ & $\mathrm{O} 2-\mathrm{Cu} 1-\mathrm{O}^{\# 1}$ & $76.4(1)$ \\
\hline O3-Cu1-N1 & $93.8(1)$ & O2-Cu1-N1 & $95.5(1)$ & $\mathrm{O} 2-\mathrm{Cu} 1-\mathrm{N} 1^{\# 1}$ & $171.5(1)$ \\
\hline $\mathrm{O} 3-\mathrm{Cu} 1-\mathrm{Cu} 1^{\# 1}$ & 132.4(1) & $\mathrm{O} 2-\mathrm{Cu} 1-\mathrm{Cu} 1^{\# 1}$ & $38.3(1)$ & $\mathrm{O} 2-\mathrm{Cu} 1^{\# 1}-\mathrm{Cu} 1$ & $38.1(1)$ \\
\hline $\mathrm{N} 1-\mathrm{Cu} 1-\mathrm{Cu} 1^{\# 1}$ & $133.7(1)$ & C3-N1-Cu1 & $125.5(2)$ & O1-N1-Cu1 & $122.4(2)$ \\
\hline C2-O2-Cu1 & $125.7(2)$ & $\mathrm{C} 2-\mathrm{O} 2-\mathrm{Cu} 1^{\# 1}$ & $130.0(2)$ & $\mathrm{Cu} 1-\mathrm{O} 2-\mathrm{Cu} 1^{\# 1}$ & $103.6(1)$ \\
\hline C5-O3-Cu1 & $128.3(2)$ & - & - & - & - \\
\hline
\end{tabular}

Symmetry transformations used to generate equivalent atoms: ${ }^{\# 1}-\mathrm{x},-\mathrm{y}+1,-\mathrm{z}+1$. 
Single-crystal X-ray structure revealed that the complex is a neutral homobinuclear entity with crystallographic inversion symmetry. The ORTEP shows that two $\left[\mathrm{Cu}\left(\mathrm{L}^{2}\right)\right]$ moieties in the same molecule are bridged together through two alkoxo bridges, each of which comes from the new ligand $\mathrm{H}_{2} \mathrm{~L}^{2}$. The whole complex sits on a center of inversion forming the $\mu$-dialkoxo-bridged binuclear structure with both tetra-coordinated $\mathrm{Cu}(\mathrm{II})$ centers. This geometry can be best described as slightly distorted square-planar with $\mathrm{CuN}_{1} \mathrm{O}_{3}$ coordination (one oxime $\mathrm{N} 1$ atom, one phenoxo $\mathrm{O} 3$ atom and two bridging alkoxo $\mathrm{O} 2$ and $\mathrm{O}^{\# 1}$ atoms). Thus, a planar $\mathrm{Cu}_{2} \mathrm{O}_{2}$ core is formed by two $\mathrm{Cu}(\mathrm{II})$ ions and their bridging two alkoxo oxygen atoms with a $\mathrm{Cu} 1 \cdots \mathrm{Cu} 1^{\# 1}$ separation of 2.999(1) $\AA$. The distance of $\mathrm{Cu} 1 \cdots \mathrm{Cu} 1^{\# 1}$ is relatively too long to be considered as intramolecular $\mathrm{Cu}-\mathrm{Cu}$ bonding. The bridging $\mathrm{Cu}-\mathrm{O}$ bonds are slightly asymmetric, one being short (Cu1-O2) with $1.904(2) \AA$ and one long $\left(\mathrm{Cu} 1-\mathrm{O} 2^{\# 1}\right)$ is $1.912(2) \AA$. The bond lengths $\mathrm{Cu} 1-\mathrm{O} 3$ and $\mathrm{Cu} 1-\mathrm{N} 1$ are $1.879(2)$ and 1.936(3) $\AA$, respectively. The four-membered ring $\mathrm{Cu} 1-\mathrm{O} 2-\mathrm{Cu} 1^{\# 1}-\mathrm{O} 2^{\# 1}$ is exactly planar as required by symmetry. The angles $\mathrm{Cu} 1-\mathrm{O} 2-$ $\mathrm{Cu}^{\# 1}$ and $\mathrm{O} 2-\mathrm{Cu} 1-\mathrm{O} 2^{\# 1}$ are 103.6(1) and 76.4(1) ${ }^{\circ}$, respectively. The dihedral angle of the two planes O2-Cu1-O2 $2^{\# 1}$ and O3$\mathrm{Cu} 1^{\# 1}-\mathrm{N} 1$ is $3.22^{\circ}$ and the $\mathrm{Cu} 1$ atom deviates by 0.004(3) $\AA$ from the mean plane defined by the atoms $\mathrm{O} 2, \mathrm{O} 2^{\# 1}, \mathrm{O} 3, \mathrm{~N} 1$.

Intermolecular interactions of $\left[\mathrm{Cu}_{2}\left(\mathbf{L}^{2}\right)_{2}\right]$ : The $\mathrm{Cu}(\mathrm{II})$ complex in the crystal self-assembles through 12 intermolecular hydrogen bonds. The hydrogen bond data are listed in Table-3. In the crystal structure, four intermolecular hydrogen bonds, C1-H1A … 3 , are formed between the methylene unit (C1-H1A) of the O-alkyl chain and the phenolic O3 atom of the $\left(\mathrm{L}^{2}\right)^{2-}$ unit, linking the neighboring molecules into an infinite chain parallel to the a axis, as illustrated in Fig. 2. The molecules are further linked by four pairs of hydrogen bonds, C3$\mathrm{H} 3 \cdots \mathrm{O} 4$ and $\mathrm{C} 10-\mathrm{H} 10 \mathrm{~B} \cdots \mathrm{O} 1$, forming an infinite 2D layer structure along the crystallographic ac plane (Fig. 3). The C3$\mathrm{H} 3 \cdots \mathrm{O} 4$ hydrogen bonds are formed between the $-\mathrm{C} 3 \mathrm{H} 3$ unit of the oxime groups and the $\mathrm{O} 4$ atom of the methoxy group, while the hydrogen bonds $\mathrm{C} 10-\mathrm{H} 10 \mathrm{~B} \cdots \mathrm{O} 1$ are formed between $-\mathrm{C} 10 \mathrm{H} 10 \mathrm{~B}$ unit of the methoxy group and the $\mathrm{O} 1$ atom of the oxime groups. Thus, each complex is linked to ten other molecules into an infinite 3D supramolecular network through intermolecular $\mathrm{C}-\mathrm{H} \cdots \mathrm{O}$ hydrogen bonds.

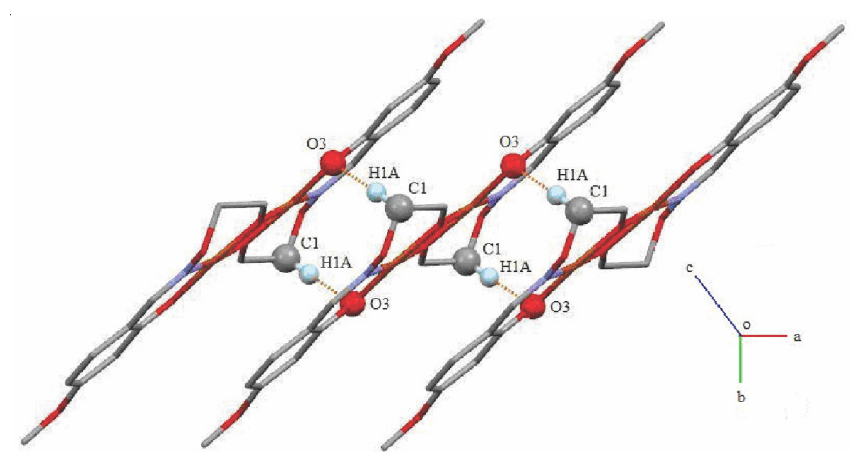

Fig. 2. (Colour online). View of the 1D chain motif of the complex units along the a axis (hydrogen atoms, except those forming hydrogen bonds, are omitted for clarity)
TABLE-3

DATA FOR HYDROGEN-BONDING INTERACTIONS $\left(\AA,^{\circ}\right)$

\begin{tabular}{lcccc}
\multicolumn{1}{c}{$\mathrm{D}-\mathrm{H} \cdots \mathrm{A}$} & $\mathrm{d}(\mathrm{D}-\mathrm{H})$ & $\mathrm{d}(\mathrm{H} \cdots \mathrm{A})$ & $\mathrm{d}(\mathrm{D} \cdots \mathrm{A})$ & $\angle \mathrm{D}-\mathrm{H} \cdots \mathrm{A}$ \\
\hline $\mathrm{C} 10-\mathrm{H} 10 \mathrm{~B} \cdots \mathrm{O} 1$ & 0.96 & 2.62 & $3.51(3)$ & 155 \\
$\mathrm{C} 3-\mathrm{H} 3 \cdots \mathrm{O} 4$ & 0.93 & 2.59 & $3.49(3)$ & 162 \\
$\mathrm{C} 1-\mathrm{H} 1 \mathrm{~A} \cdots \mathrm{O} 3$ & 0.97 & 2.50 & $3.43(3)$ & 160 \\
\hline
\end{tabular}

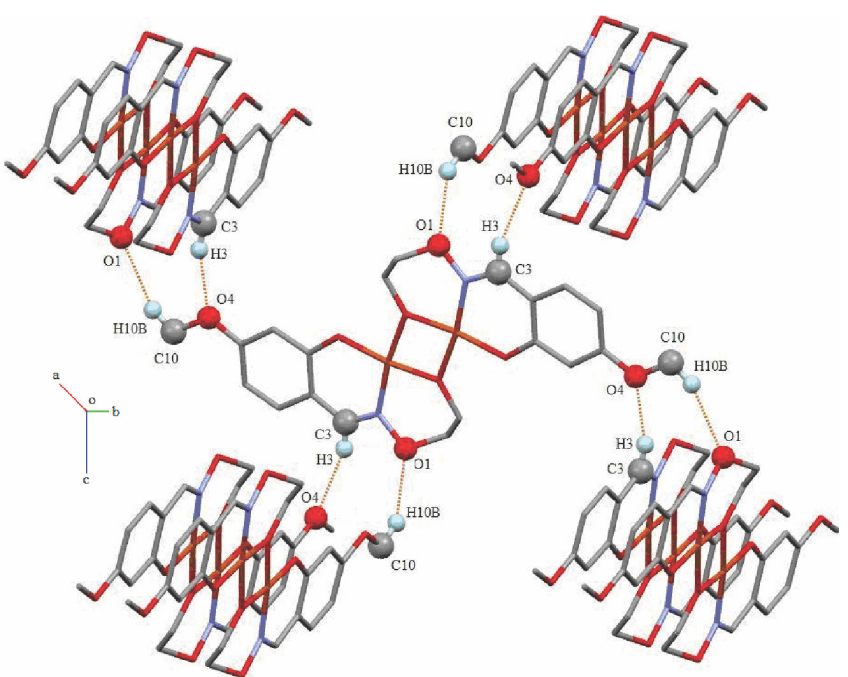

Fig. 3. (colour online). View of the 2D layer motif along the ac plane (hydrogen atoms, except those forming hydrogen bonds, are omitted for clarity)

\section{ACKNOWLEDGEMENTS}

This work was supported by the Foundation of Preparative Research of Jin-Chuan Corporation (No. 209125-1102, 1103), which is gratefully acknowledged.

\section{REFERENCES}

1. (a) W.K. Dong, X.N. He, C.M. Dong, L. Wang, J.K. Zhong, X. Chen and T.Z. Yu, Z. Kristallogr. NCS., 222, 289 (2007); (b) W.K. Dong, J.G. Duan, H.L. Wu, J.Y. Shi and T.Z. Yu, Z. Kristallogr. NCS, 221, 555 (2006); (c) W.K. Dong and Y.J. Ding, Cryst. Res. Technol., 43, 321 (2007); (d) W.K. Dong, J.Y. Shi, J.K. Zhong, Y.X. Sun and J.G. Duan, Struct. Chem., 19, 95 (2008); (e) W.K. Dong, J.Y. Shi, J.K. Zhong, Y.Q. Tian and J.G. Duan, Chin. J. Inorg. Chem., 24, 10 (2008); (f) W.K. Dong, Y.X. Sun, X.N. He, J.F. Tong and J.C. Wu, Spectrochim. Acta A, 76, 476 (2010); (g) W.K. Dong, Y.X. Sun, Y.P. Zhang, L. Li, X.N. He and X.L. Tang, Inorg. Chim. Acta, 362, 117 (2009); (h) W.K. Dong, J.G. Duan, Y.H. Guan, J.Y. Shi and C.Y. Zhao, Inorg. Chim. Acta, 362, 1129 (2009); (i) W.K. Dong, K.Q. Li, Y. Zhang, L. Xu, L. Wang and X.Y. Dong, Asian J. Chem., 25, 4398 (2013); () G. Li, L. Wang, Y.-H. Yang and Y.-J. Zhang, Asian J. Chem., 25, (2013) (In press).

2. S. Akine, W.K. Dong and T. Nabeshima, Inorg. Chem., 45, 4677 (2006).

3. J. Costamagna, J. Vargas and R. Latorre, Coord. Chem. Rev., 119, 67 (1992).

4. H. Miyasaka, N. Matsumoto and H. Okawa, J. Am. Chem. Soc., 118, 981 (1996).

5. T.K. Ronson, H. Adams and M.D. Ward, Inorg. Chim. Acta, 358, 1943 (2005).

6. L. Canali and D.C. Sherrington, Chem. Soc. Rev., 28, 85 (1999).

7. S. Akine, T. Taniguchi, W.K. Dong and T. Nabeshima, J. Org. Chem., 70, 1704 (2005).

8. X.R. Bu, X.Z. You and Q.J. Meng, Comments Inorg. Chem., 9, 221 (1990).

9. Q.J. Meng, X.R. Bu and S.H. Sun, Chin. J. Inorg. Chem., 6, 124 (1990).

10. J. Madarasz, P. Bombicz, M. Czugler and G. Pokol, Polyhedron, 19, 457 (2000).

11. A. Karadag, V.T. Yilmaz and C. Thoene, Polyhedron, 20, 635 (2001). 